\title{
Educative Tradition and Islamic Schools in Indonesia
}

\author{
ChARLENE TAN (Nanyang Technological University, Singapore)
}

\begin{abstract}
An Islamic school that subscribes to an educative tradition is essentially one that sees compatibility between the inculcation of religious values and the acquisition of 'modern' knowledge and dispositions. This article argues that most Islamic schools in Indonesia reside in an educative tradition as evident in three main ways. First, most Islamic schools in Indonesia are keen to obtain knowledge from both religious subjects and modern 'secular' subjects. Secondly, an increasing number of Islamic schools have incorporated student-centred pedagogies so that their students do not simply learn by rote or memorisation. Thirdly, many Islamic schools provide a variety of student activities to develop the students' life skills and leadership abilities so as to encourage their students to internalise and put into practice the principles and values they have learnt. Notwithstanding its promotion of an educative tradition, many Islamic schools in Indonesia face a perennial challenge in infusing Islamic principles and values into the teaching of modern 'secular' subjects.

Keywords: Curricula, educative tradition, Indonesia, Islam, Islamic schools, pedagogy
\end{abstract}

\section{Introduction}

Indonesia is the most populous Muslim country in the world with over 200 million Muslims. With more than 50,000 Islamic schools in the country, the religious teachings in these schools have a direct and long-lasting impact on the Islamic orientation and lives of Muslims in the country and elsewhere. It is therefore instructive to critically examine the educational philosophy, curriculum and pedagogy of Islamic schools in Indonesia. This article surveys the Islamic schools in Indonesia using the conceptual tool of an educative tradition. Given the vast number and diversity of Islamic schools in Indonesia, it is impossible for this article to give a detailed discussion of all the Islamic schools in the country. Instead, this article aims to provide a broad overview of the Islamic schools, identify some common trends and highlight some examples. The research data on Indonesia are obtained from literature review, document analysis, and fieldwork conducted in May 2010 with 12 Islamic schools in Indonesia. For a start, it is helpful to introduce the concept of an educative tradition.

\section{An Educative Tradition}

An educative tradition is essentially one that fosters the development of pluralism, rationality and autonomy in its students. An Islamic school that adheres to an educative 
tradition is one that offers a broad-based curriculum, is willing to learn from various traditions and sources, and is adaptable to changing times and places. Its students not only master the facts but also are equipped with the capacity and willingness to provide the evidential justification for these facts in an age-appropriate manner. The corresponding pedagogy should promote engaged learning: this entails the construction of knowledge (not only transmission of knowledge), understanding (not only rote memorisation), social constructivism (not only individual study), self-directed learning (not only teacherdirected), and learning about learning (not only learning about subjects). ${ }^{1}$ The students should ideally be exposed to a variety of learning methods such as lectures, group discussions, experiments and independent research. The school's programmes, activities and learning environment should also nurture the students' freedom of thought and action. The students should be encouraged to accept, be motivated by and order their lives based on a Muslim tradition that they have chosen for themselves.

An educative tradition is one that sees compatibility between religious teachings and 'modern' knowledge. Fazlur Rahman outlines two basic Muslim approaches to 'modern' knowledge, albeit with variations in between:

(1) that the acquisition of modern knowledge be limited to the practical technological sphere, since at the level of pure thought Muslims need not need Western intellectual products - indeed, that these should be avoided, since they might create doubt and disruption in the Muslim mind, for which the traditional Islamic system of belief already provides satisfactory answers to ultimate questions of world view; and (2) that Muslims without fear can and ought to acquire not only Western technology but also its intellectualism, since no type of knowledge can be harmful, and that in any case science and pure thought were assiduously cultivated by Muslims in the early medieval centuries, whence they were taken over by Europeans themselves. ${ }^{2}$

Adopting the first option, some Muslims believe that non-Islamic cultural knowledge, beliefs, values and practices, especially originating from 'the West', must be avoided and rejected at all cost. Only then, they argue, could Muslims continue to preserve and protect their treasured Islamic traditions. As long as the adoption of practical technological knowledge from the West is kept to its utilitarian purpose to equip the students to meet the challenges of a knowledge-based economy, it is 'safe' for Muslims to learn from the West. Otherwise, Muslims would be in danger of being 'Westernised', which is perceived to be un-Islamic and robbing the ummah (Muslim community) of its religious and cultural heritage. $^{3}$

The other option, as highlighted by Rahman, is to accept not just Western technology but also its intellectualism. But the question here is whether Western intellectualism is perceived to be 'Islamic'. On the one hand, there are Muslims who argue that globalisation, which is closely associated with modern Western knowledge, is an insidious and unIslamic. For example, Muḥammad 'Abid al-Jābirī associates globalisation with cultural

TAN 2009: 78-82

2 RAHMAN 1982: 46-7.

3 MOTEN 2005: 246.

$J A I S ・ 14$ (2014): 47-62 
hegemony; and Muțạc Șafadī views globalisation as "a single cultural project that controls the whole world, stamping it with its own personality, within a global strategy whose project of 'totalitarian technology' devours spatial and historical distances as well as national characteristics in order to establish 'the New World Order' in a grand global (kawniyyah) drama". ${ }^{4}$ Other Muslims, however, do not share the same view, and aver instead that all knowledge, whether 'Western' or otherwise, comes from God. Both "religious" and "secular" knowledge are integrated in Islamic thought under two main types: rational sciences (al-ulüm al-'aqliyyah) or intellectual sciences, and the traditional sciences (al-ulüm al-naqliyyah) or revealed knowledge. The first type of knowledge, according to Syed Farid Alata, is knowledge that arises from man's capacity for reason, sense perception, and observation while traditional sciences refer to knowledge that is devolved to man via Revelation. Traditional sciences, he adds, includes disciplines termed as "modern" today: logic, physics, metaphysics, geometry, arithmetic, medicine, geography, chemistry, biology, music, astronomy, and science of civilisation. ${ }^{5}$

It is important to note that the acceptance of 'secular' knowledge or 'modern' subject is not foreign to the Islamic heritage. It has been noted that the Islamic educational institutions during the Ottoman Empire incorporated "specific sciences" (al-ulüm aljuz'iyyah) which were mathematics (hisāb), geometry (handasah), astronomy (hay'ah) and practical philosophy (hikmah). Far from mere memorisation, the madrasahs also included "instrumental sciences" (al-'ulüm al-'âliyyah) where students learnt, among other things, the art of rhetoric in terms of eloquent elocution, literary style and artful composition. ${ }^{6}$ It should also be pointed out that 'modern'/'Western' student-centred pedagogies are not new to the Islamic traditions. Student-centred pedagogies such as problem solving, dialogue, discussion, disputation and application have been propagated by Muslim scholars and practiced in the Islamic context since the medieval times. ${ }^{7}$ The next section provides an overview of Islamic schools in Indonesia.

\section{An Overview of Islamic Schools in Indonesia}

Islamic teaching started in Indonesia as early as around the $13^{\text {th }}$ century in the form of Qur'anic study in village mosques, prayer houses and the private homes of community religious teachers for young children of six to eleven years. ${ }^{8}$ Over time, different types of Islamic schools came into existence in different parts of Indonesia, such as pesantren and pondok (both mostly in Java and Kalimantan), surau (in West Sumatra), dayah (in Aceh), madrasah and sekolah Islam (Islamic schools), with pesantren, pondok, surau, and dayah generally regarded as 'traditional' Islamic educational institutions that have a long history dating from the early introduction of Islam in Indonesia. ${ }^{9}$ The Islamic teaching, as taught in

4 All cited in SHBOUl 2004: 53, 57.

5 Alatas 2006: 169.

6 IDRIZ \& al-ATTAS 2007: 7-8. For a useful historical survey of the evolving relationship between Islam and the enterprise of science from the eighth century to the present time, see IQBAL 2009.

7 For more details, see TAN \& ABBAS 2009: 25-39.

8 HEFNER 2007: 59.

9 AZRA 2014: 59-75. 
the traditional pesantrens, are based on "the Ash'ari doctrine (as mediated especially by Sanusi's works), the Shafi'i madhhab (with nominal acceptance of the other three Sunni madhhab), and the ethical and pietistic mysticism of Ghazali and related writers". ${ }^{10}$ Of the 50,000 Islamic schools in Indonesia, 16015 of them are pesantrens (Islamic boarding schools) and 37,000 of them are madrasahs (Islamic day schools). ${ }^{11}$ The enrolments in Islamic schools have been increasing since the late 1980s. Currently about 5.7 million or 13 percent of the 44 million students are enrolled in the formal educational system are enrolled in madrasahs. ${ }^{12}$ Islamic schools in Indonesia can be divided into three main types: pesantrens, madrasahs and Sekolah Islams. There is no significant city/country divide or regional diversity in terms of the types of Islamic schools found in Indonesia. In general, most pesantrens are located in the countryside whereas more madrasahs and Sekolah Islams are found in urban areas in cities such as Jakarta. ${ }^{13}$ Of the three types of Islamic schools, Sekolah Islam is particularly oriented towards modern city life where many middle-class Muslim professionals are keen to send their children to such schools. However, the main differences among the Islamic schools are not so much city/countryside or regional, but rather their educational philosophy and curriculum. The next section elaborates on each type of Islamic schools in Indonesia.

\section{Pesantrens}

Of the three types of Islamic schools, pesantrens are the oldest and are regarded as the bastion of Islamic knowledge as well as the main provider of Islamic scholars and teachers. Focussing on the transmission of the classical Islamic sciences, pesantrens teach subjects such as Qur'an, hadīth (collection of sayings and deeds of the Prophet Muhammad), jurisprudence (fiqh), Arabic grammar, mysticism (tașawwuf), and the Arab sciences $(\bar{a} l \bar{a} t) .{ }^{14} \mathrm{~A}$ distinctive feature of pesantren education is the learning of classical Islamic commentaries known as kitab kuning (literally, 'yellow books'). Although pesantrens started with teaching purely religious subjects, pesantrens today supplement their religious

10 For more details on the religious curriculum in pesantrens, see VAN BRUINESSEN 1994: 121-145.

11 There is some controversy over the exact number of Islamic schools in Indonesia. Azyumardi Azra, Dina Afrianty and Robert W. Hefner, in an essay published in 2007, state that there are 10,000 pesantrens and 37,000 madrasahs, adding to a total of 50,000. See AZRA / AFRIANTY / HEFNER 2007: 173; HEFNER 2007: 59. However, the total figure is likely to be over 50000 based on a higher number of pesantrens. Rather than 10,000 pesantrens, H. Imron Arifin and Muhammad Slamet note that there are 16,015 pesantrens based on the statistics obtained from the Department of Religious Affairs in 2006, as cited in ARIFIN \& SLAMET 2010: 38.

12 AZRA / AFRIANTY / HEFNER 2007: 173. I should clarify that enrolment statistics do not reflect the actual number of Islamic schools due to the problem of double counting. According to AZRA / AFRIANTY / HEFNER, many pesantrens have madrasahs or public schools (known as general schools in Indonesia) in their compound but these institutions are counted as separate entities. The same applies to the number of students; students who attend a public school in the morning and an Islamic school after school hours are counted twice. Nevertheless, it is fair to say that there are about 50,000 Islamic schools in Indonesia.

13 HASAN 2008: 247.

14 AZRA /AFRIANTY / HEFNER 2007: 175 
studies with a general elementary education. This change was partly due to state reforms in the late 1970s. ${ }^{15}$ Besides non-religious subjects, many pesantrens have also offered vocational courses such as agricultural skills, vehicle repair and business enterprising skills.

Pesantrens can be further divided into three types: traditional, modern, and independent. ${ }^{16} \mathrm{~A}$ "traditional pesantren" tends to focus on traditional Islam and is likely to be ideologically affiliated with Nahdlatul Ulama (NU). NU, which commands a bigger following, is an association of kyais - Muslim scholars who usually have their own pesantrens and teach classical Islamic texts to their students. ${ }^{17} \mathrm{~A}$ traditional pesantren is distinguished by its endorsement of devotional and mystical beliefs and practices. An example is visits to the graves of local saints and great kyais to obtain blessings and barakah (holiness, virtue as inherent spiritual power). Other practices include chanting religious formulae (zikir, literally means remembrance of God) and specific devotions and mystical exercises imparted by the kyai to their followers. ${ }^{18}$ The second type is a "modern pesantren". As its name implies, it modernises pesantren education by introducing a structured grade system, classrooms, textbooks and an ethos of reform and progress. ${ }^{19}$ Most modern pesantrens are affiliated with Muhammadiyah that is a mass-based Muslim association like NU. But unlike NU, it is "reformist" in the sense that it rejects the mystical and devotional beliefs and practices endorsed by $\mathrm{NU}$ and found in traditional pesantrens. Muhammadiyah views these beliefs and practices as syncretistic and unIslamic. ${ }^{20}$ The third type is "independent pesantren" that is not associated with NU or Muhammadiyah, and tends to adopt Salafi ideological beliefs (more on this later).

\section{Madrasah}

Unlike the common meaning of a madrasah as an Islamic college or Islamic institution of higher learning, this term refers to an Islamic day school in the Indonesian context. Combining traditional religious education with a broad general component, the majority of madrasahs are privately owned with state-owned madrasahs comprising between 6.4 percent and 13 percent from the primary to the senior secondary levels. ${ }^{21}$ Besides being a non-boarding school, the madrasahs are distinguished from the pesantrens in their mission and modern approaches to the school set-up, curriculum and pedagogy. Unlike pesantrens

15 AZRA / AFRIANTY / HEFNER 2007: 176.

16 This typology of pesantrens is taken from BURHANUDIN \& JAMHARI 2006: 404.

17 DHOFIER 1999: 34. Dhofier adds that strictly speaking, only ulama (Islamic scholars) who lead pesantrens in Central and East Java are called a kyai; in West Java, they are "ajengan". However, the term "kyai" has transcended territorial boundaries and is generally used to refer to traditionalist ulama in Indonesia. See ibid.

18 See VAN BRUINESSEN 1994: 124; VAN BRUINESSEN 2008: 218; LuKENS-Bull 2005: 18; GeERTZ 1968: 49 .

19 BURHANUDIN \& JAMHARI 2006: 409.

20 VAN BRUINESSEN 2008: 218. The mass support for these two organisations is seen in a nation-wide survey where 42 percent of the respondents identified themselves with NU and 12 percent identified themselves with Muhammadiyah, see ibid.: 219.

21 SAEED 1999: 181; AZRA / AFRIANTY / HEFNER 2007: 180. 
that aim to nurture religious scholars, madrasahs are set up to create "learning Muslims" who are ready for secular professional jobs. ${ }^{22}$ Similar to Dutch government and Christian missionary schools, the madrasahs offer their students different levels of graded instruction, modern classrooms with blackboards, textbooks and structured assessments. All madrasahs today adopt a government-approved madrasah curriculum consisting of 70 percent general subjects and 30 percent religious subjects. Recognised as on par with the public schools in the Educational Act of No 2/1989, madrasahs follow the national curricula fully and their graduates may continue their studies at both Islamic and secular public universities. While public schools offer only two hours of Islamic Religious Studies (Pendidikan Agama Islam) per week, the madrasahs offer about five or six hours per week. Furthermore, the madrasah offer additional Islamic subjects such as Quran, Hadith, Fiqh (jurisprudence), Aqidah (theology) Akhlak (virtue) and Islamic history.

\section{Sekolah Islam}

The third type of Islamic school is Sekolah Islam (Islamic school). ${ }^{23}$ As stated in the introductory chapter, an "Islamic school" is used to refer to any educational institution that emphasises the transmission of Islamic knowledge and inculcation of Islamic values and ethos. Many Sekolah Islams are found in urban areas and cater largely for Muslim students from middle-class family background. This contributes to the general perception that they are elite Islamic schools. Their popularity is due to the desire of middle-class parents who wish to provide a modern Islamic schooling for their children that offers a high academic standard in general subjects within an Islamic environment. Charging relatively high school fees compared to pesantrens and madrasahs, these schools are well-equipped with modern facilities such as air-conditioned classrooms, libraries, language, science and computer labs, and multi-media facilities. They are also staffed by teachers and managers who are generally highly qualified and competent. ${ }^{24}$

The students in Sekolah Islams do not concentrate on learning Islamic courses such as Islamic jurisprudence or Islamic theology. Rather, their attention is on general subjects such as science, history, social studies, and foreign languages. On the other hand, Sekolah Islams surpass the public schools by allocating more hours to religious instruction: an average of 4 or 5 lesson hours as compared to 2 lesson hours per week in the public schools. On top of that, they include Arabic language and Qur'anic studies in their curriculum. Sekolah Islams combine a quality general education with Islamic ethos and morals; importance is placed on Islamic practices such as prayer, and attempts are made to infuse Islamic principles and values into the curriculum. This type of school is also known for offering its students a rich variety of extra-curricular activities so as to inculcate Islamic values through these activities.

22 BURHANUDIN \& JAMHARI 2006: 409.

23 Although 'Sekolah Islam' literally means 'Islamic school', I will refer to the Indonesian term so as not to confuse this type of school with the generic term 'Islamic school'.

24 BURHANUDIN \& JAMHARI 2006: 412. 


\section{Educative Tradition and Islamic Schools in Indonesia}

It is arguable that most Islamic schools in Indonesia reflect an educative tradition: the inclusion of modern 'secular' (non-religious) subjects, the adoption of student-centred pedagogies, and the provision of a variety of student activities. First, many Islamic schools are keen to obtain knowledge from both religious subjects and modern 'secular' or nonreligious subjects (known as "general subjects" in Indonesia). By being open to new ideas and latest inventions from a variety of traditions and sources, including from the United States and other Western countries, the Islamic schools remain adaptable to changing times and places. Unsurprisingly, the Islamic educational system in Indonesia has been described as "among the most open and innovative in the world" for the willingness of Indonesian Muslim educators to go beyond religious studies to offer marketable skills and general education. $^{25}$

Secondly, an increasing number of Islamic schools have incorporated student-centred pedagogies so that their students do not simply learn by rote or memorisation. ${ }^{26}$ While the traditional didactic teaching methods of teaching (bandongan and sorogan) are still widely used in the pesantrens, many pesantrens have expanded and diversified their teaching repertoires. Since the general subjects are based on the national curriculum, the teaching methods for these subjects are similar to those used in public schools. Through activities such as laboratory experiments for science subjects, the students acquire not just facts but the scientific inquiry and evidential justification for the facts. It is also common for Islamic schools to capitalise on Information and Communication Technology (ICT) and multimedia resources in promoting engaged learning.

Finally, many Islamic schools provide a variety of student activities to develop the students' life skills and leadership abilities. This goes towards helping students to internalise and put into practice the principles and values they have learnt. Students are encouraged to be involved in a cornucopia of activities both during and outside the official school hours.

To further illustrate the educative tradition of Islamic schools in Indonesia, the next section focuses on three Islamic schools in Indonesia that reflect an educative tradition. The first example is a pesantren that was established in 1999 as a boarding school for over 550 secondary and high school students. A high-achieving school, its students have consistently performed well in the national examinations and won many science Olympiad competitions at the national level. The pesantren envisions itself as "a school that is effective, modern and of high quality so as to develop a generation of leaders for the nation". ${ }^{27}$ By providing an "effective and conducive learning" surrounded by Islamic ethos, it aims to nurture students who "have the critical, logical, systematic and creative thinking, knowledgeable with content mastery, and careful and clever to overcome any problems encountered". ${ }^{28}$

25 AZRA / AFRIANTY / HEFNER 2007: 173-4.

26 BURHANUDIN \& JAMHARI 2006: 404.

27 Information from the school website.

28 Dto. 
The pesantren promotes an educative tradition in three ways. First, it aspires to help students obtain knowledge from both religious subjects and modern 'secular' subjects. Highlighting the need to be a 'modern school', the school leader explained:

We want the school to be an effective, modern school, not too traditional and keeping on developing and expanding according to the trends of modern life. And it is of high quality. And that we are able to produce kader [the select few] who are leaders of the community. ${ }^{29}$

Part of being 'leaders of the community' is to be law-abiding citizens; the school leader maintained that "the graduates will be citizens and they should be law-abiding citizens, we hope that they will not turn out to be terrorists, radicals". ${ }^{30}$

Secondly, the pesantren has incorporated student-centred pedagogies so that their students do not simply learn passively. Eschewing a didactic pedagogy, the school leader explained, "we sincerely believe that you must have variations in your teaching; of course, you can use lecture style when you need to explain some concepts, but it cannot be all the time". ${ }^{31}$ Examples of student-centred methods adopted in the peseantren are getting students to complete project work, give presentation, and create their own blogs. The school leader gave the following example of a student-centred learning:

We actually started 'Essay Writing' earlier, in Class 10 and Class 11, where they are trained to do literature research and writing. And when they go to the next level of Class 13, they will do 'Formal Writing', where they would do in-depth research on a topic, followed by a presentation and a write-up. You could find their write-ups in the library I think. This particular training helps our students in their preparation for their studies in the universities. They would not have any problems to do the assignments at the universities due to the exposure that they had here. ${ }^{32}$

Thirdly, the pesantren provides a variety of student activities so as to promote active the application of knowledge and values learnt. Its objective is to "support the personal growth of students who have the spirit of entrepreneurship and life skills so as to prepare them to enter the workforce". ${ }^{33}$ Activities include school debate, robot programming and scientific experiments, as well as sports such as basketball, swimming and football.

The next example is a madrasah that offers schooling from elementary to high school levels. Started in the 1970s, it has over 2,000 students with students mostly from middle income households with educated parents living in the city. The madrasah aspires to be "more than just an Islamic school" in the sense that it aims to integrate Islamic guidance with science and technology. ${ }^{34}$ Cautioning against the effect of 'moral destruction' brought about by globalisation, the madrasah maintains the need for madrasahs as "an alternative

29 Interview with a senior staff member of the school, 11 May 2010.

30 Ibid.

31 Ibid.

32 Ibid.

33 Information from the school website.

34 Ibid. 
that has an important role in the formation of character, personality, and the quality of the nation in the future". ${ }^{35}$ The director of the madrasah explains the mission of the school:

Our mission is to be a leading and prominent Islamic educational centre, in knowledge, religion and steeped in Indonesian character and in preparing the students for the global society. This is in line with the aims of the original founders which hope to establish a school that is good academically, excellent intellectually, and at the same has high moral character. The balance of these three aspects is the aim of the pioneers. ${ }^{36}$

The madrasah offers both religious subjects (as expected of a religious school) and modern 'secular' subjects (known as 'general subjects') to students that are similar to those in public schools. Seeing no issue with encouraging students to learn 'modern' subjects such as science and technology and Islamic teachings, a teacher asserted, "In our country, we always focus on the scientific method. Just because it comes from the west, it is not Christianity. We do not think of it in that way". 37

That a student-centred approach is emphasised is noted in the school brochure: "The learning process is student-centred with active learning". ${ }^{38}$ The director of the school elaborated on the meaning of active learning:

The principle is that the teacher's role is as the facilitator, and to give as much opportunities for the students to be highly active in class. ... We are encouraging active learning here, with various educational strategies, such as through cooperative learning, discussion, experiments, enquiry, exploratory, etc. ${ }^{39}$

Complementing active learning are various student programmes to develop $21^{\text {st }}$ century skills such as computer skills and research skills, as well as holistic education through extra-curricular activities in the sports and arts. Enhancing the students' learning are wellequipped facilities such as computer laboratory, sports hall and a library with more than 9,000 books.

The last example is a madrasah that was established in 1997 with a current enrolment of over 300 high school students. Its mission is to "prepare future leaders who mastered science and technology, have a high fighting spirit, are creative, innovative and have the foundation of a strong faith and piety". ${ }^{40}$ A high-achieving school, many of its students have graduated from the school with excellent results, successfully enrolled in universities and won prizes in the national as well as international science Olympiad competitions.

Underscoring the integration of religious subjects and modern 'secular' subjects, the school's curriculum combines the mastery of science and technology with the inculcation of religious faith and piety. Such an integrated vision is welcomed by the parents who want their children to excel academically within a religious environment. A school leader

35 Ibid.

36 Interview with the director of the school, 11 May 2010.

37 Interview with a teacher of the school, 11 May 2010.

38 Information from the school brochure.

39 Interview with the director of the school, 11 May 2010.

40 Information from the school website. 
explained, "The parents acknowledged that the preparation for the next life is what they cannot provide for their children on their own, that is where they find that they can find that our school is the school that can provide the two type of "provisions' for their children".

In terms of teaching method, the school states that "the approach used in teaching and learning is through active student learning". ${ }^{42}$ This approach requires its teachers to use a variety of teaching methods and activities that promote student engagement. As explained by a school leader:

We have variety of methodologies, depending on respective subjects. For example, for language, they may decide and arrange how much they should do for listening, writing, reading, grammar etc. They may use language laboratory or presentations and so forth. For other subjects, we may use laboratory, internet search, or using educational CDs, practicum and so on. The same goes for religious studies, when they are learning how to perform solat [prayers], they will have practical lessons in solat. If they are to learn how to wash the corpse, then there would be a mannequin and the whole process will be done and practised. ${ }^{43}$

Active learning is supported with adequate facilities such as laboratories, a multimedia room, library, greenhouse and instructional media such as LCD projector and internet facilities. An example of active learning adopted in the school is project work where students carried out their own research based on a theme assigned by the teacher, such as research on basic figh (Islamic jurisprudence). A holistic education is provided through a variety of student activities such as leadership skills through the programme 'Pengembangan Diri' (Self-Development).

\section{Discussion}

Two observations about Islamic schools in Indonesia can be made. First, we see from our discussion of Indonesian Islamic schools that they generally reside in an educative tradition. They are pluralist in the sense that they embrace non-religious subjects and promote rationality and autonomy through their student-centred pedagogies and student activities. With the teaching and learning of general subject such as English, Mathematics, Sciences, epistemological pluralism is introduced to the students. ${ }^{44}$ Students of Indonesian Islamic schools are exposed to knowledge from various disciplines and sources. They no longer learn purely Islamic subjects (as in pesantrens of old) but the history and geography

41 Interview with a senior staff member of the school, 10 May 2010.

42 Information from the school website.

43 Interview with a senior staff member of the school, 10 May 2010.

44 We have not discussed political pluralism as this is less relevant than epistemological pluralism in the schooling context. But it should be noted that political pluralism has a strong presence in Indonesia, as seen in the strong participation of political parties, the populace's positive attitude towards democracy, and general rejection the establishment of an Islamic state through violent means. It is beyond the scope of this article to study the political developments of Islam and its relationship with the state in Indonesia. Interested readers may refer to HEFNER 2000, ASSYAUKANIE 2009, PLATZDASCH 2009, HEFNER 2007. 
of countries outside Indonesia, and the English language and culture of English-speaking countries. A pluralist attitude opens the students' vistas to the rest of the world, and keeps them abreast of modern knowledge and skills integral for success in a globalised and digital world. A focus on modern knowledge and skills through the learning of general subjects also broadens the students' aspirations and goals in life. Whereas students simply stopped school early for work or became a religious teacher (a noble aspiration in itself) in the past, they are now more likely to aspire to seek higher education locally or overseas and become professionals in secular fields such law, medicine or business. This new aspiration is reflected and highlighted in the visions and missions of many Islamic schools who are aware of the demands of parents and students for marketable and twenty-first century skills. This orientation is especially evident in the Sekolah Islams as they are elite and highachieving schools with parents who are themselves high-flying working professionals.

Student-centred and self-directed activities such as conducting scientific experiments and writing research papers activities also motivate the students to go beyond rote learning and memorisation to explore and construct the evidential justification for the facts learnt. In the process of working with their teachers and peers on group discussions and projects, the students also develop the confidence to speak up, draw their own conclusions and support their arguments with evidence. With their teachers serving not purely as content experts but facilitators, the students also learn to relate to them within more egalitarian and consultative environment. This scenario is a far cry from a teacher-centred environment of a traditional pesantren where the kyais and religious teachers focus on textual transmission and expect unquestioned obedience from their students. Furthermore, the provision of a wide range of student activities contributes to the students' development of autonomy. Besides giving them choices to participate in an array of programmes and events, these activities also cultivate their leadership qualities, an independent spirit and other life skills such as working with others and resolving group conflicts. Of course, the extent to which a student is given the opportunity to do the above varies from school to school. A big and modern pesantren such as Gontor is more successful in enhancing its students' autonomy than a small traditional pesantren that is cash-strapped with limited resources for the students.

In terms of the question of how Islamic schools deal with dogma that contradicts the findings of modern science, it is noteworthy that an overwhelming majority of the Islamic schools in Indonesia do not face this problem. The reason is because the educational philosophy adhered to by the Islamic school leaders and other educational stakeholders in Indonesia is one that sees a compatibility between Islamic teachings and modern science. Returning to the two approaches outlined by Rahman, it is evident that the leaders and stakeholders of the Islamic educational institutions hold to the view that

Muslims without fear can and ought to acquire not only Western technology but also its intellectualism, since no type of knowledge can be harmful, and that in any case science and pure thought were assiduously cultivated by Muslims in the early medieval centuries, whence they were taken over by Europeans themselves. ${ }^{45}$

45 RAHMAN 1982: 47. 
For the Muslim educators, in Indonesia, they do not see modern knowledge as 'Western'; rather, they see 'religious' and 'Western'/'secular' knowledge as integrated in Islamic thought under two main types mentioned earlier, namely, rational/intellectual sciences (al'ulūm al-'aqliyyah) and the traditional sciences (al-'ulüm al-naqliyyah) or revealed knowledge. Rejecting the view that 'modern' subjects are 'Western' subjects, the school sees all knowledge as proceeding from God. This was highlighted by a school leader:

So, as long as we make use of the knowledge in the proper way, it belongs to Muslims, so we are not being westernised. What differs is in terms of the western culture and customs, but in terms of knowledge, it belongs to Allah and we should seek and apply it, especially if we were to see that the West apply the knowledge in the wrong or improper way, then we have to ensure that when we apply the knowledge, it should be towards something that is better. All knowledge belongs to Allah. ${ }^{46}$

The integration of religious and general subjects is achieved in the Islamic schools by the teacher alerts the students to their educational duty of knowing Allah and linking all lessons to relevant Islamic sources, principles and values. For example, a pesantren director explains that his biology teacher when teaching about fruits or creation of man will bring in the Quran and hadiths on these matters. ${ }^{47}$ The infusion of religious values is also achieved through the hidden curriculum such displaying religious teachings in the school compound.

The second observation about Islamic schools in Indonesia is that notwithstanding the potential and endeavours at integrating religious and modern 'secular'/general studies, many Islamic schools face an uphill task in doing so. A consequence of insufficient integration between general subjects with religious subjects within a coherent conceptual framework is 'educational dualism'. This refers to "the existence of an Islamic educational system with little if any general educational content alongside a secular educational system with little if any Islamic content". ${ }^{48}$ Highlighting the "knowledge dichotomy" between Islamic schools and General or public schools, Rusydy Zakaria asserts that the Islamic educational system produces graduates who have a strong religious knowledge base and moral attitudes but lack a methodological approach while general education produces graduates who are strong in methodological approaches but lack a religious knowledge base. $^{49}$ A typical view was expressed by this madrasah teacher:

Actually, in practice, educational dualism is still happening, a dichotomy between knowledge and religion, which leads to the proportion given to general studies visà-vis religious studies. This is not good actually as we wish to have integration between the two. ${ }^{50}$

\footnotetext{
46 Interview with a senior staff member of the school, 10 May 2010.

47 Interview with the director of a pesantren, 14 May 2010.

48 AZRA / AFRIANTY / HEFNER 2007: 182-3.

49 ZAKARIA 2008: 9, 82.

50 Interview with a teacher of a madrasah, 11 May 2010.
}

JAIS • 14 (2014): 47-62 
Explaining the challenge of integrating religious and non-religious (general) subjects, a teacher noted:

But in terms of the teachers' capacity to integrate the subjects with religion, we have yet to have this capacity fully in our teachers. We have some teachers who properly understand this, but there are others who do not have the capacity, especially when they need to find relevant Quranic verses that relates to the concepts or issues that they are teaching to the students. ${ }^{51}$

\section{Conclusions}

It is interesting to note that most Islamic schools in Indonesia focus on its educational mission and do not have an overt political agenda. An overwhelming majority of the Islamic schools are more concerned with religious inculcation and community involvement rather than trying to influence politics. Their 'political role', if any, is more in the form of the contributing towards a democratic civil society through peace building, conflict resolution, interfaith dialogue and the empowerment of women. ${ }^{52}$ Hefner rightly asserts that "insomuch as they have been concerned with the political issues at all, Indonesia's Muslim educators have tended to be nationalist and system-reforming rather than radical Islamist and system-upending" ${ }^{53}$ Consequently, the relation between the Islamic schools and the state has generally been smooth. Historically, Islamic schools stayed away from political involvement during then President Soeharto's rule (1967-98) as he was highly suspicious of 'political Islam,. ${ }^{54}$ His fall resulted in a flourishing of Muslim-based organisations, particularly Nahdatul Ulama (NU) and Muhammadiyah which established many Islamic schools; however, these schools are not anti-government or anti-nationalism. Rather than seeing the Islamic schools as a threat, the government has generally been supportive of their existence and continual survival. The Ministry of Religious Affairs (MORA) is in charge of the pesantrens and madrasahs while the Ministry of National Education (MONE) is in charge of the Sekolah Islam as this type of school largely adopts the system and curriculum of general schools. Besides recognising the certificates issued by the Islamic schools, MONE has also provided financial resources and facilities such as computer laboratories for some madrasahs and pesantrens. ${ }^{55}$

Notwithstanding the peaceful and apolitical nature of most Islamic schools, there exist Islamic schools, albeit in very small numbers, that promote anti-government ideology and activities that resulted in conflicts and clashes with the authority. One group of madrasahs that came into existence since the mid-1980s are the 'Salafi madrasahs' that are closely allied with the Saudi state and its own sectarian brand of Islamic thought and practice,

51 Interview with a teacher of a madrasah, 11 May 2010.

52 For an interesting case study of a pesantren that engages in promotion of a democratic civil society, see POHL 2007: 83-103.

53 HEFNER 2007: 73.

54 Mutalib 2008: 16.

55 AZRA 2014: 61. 
Wahhabism. ${ }^{56}$ Besides setting up Islamic schools such as the madrasah Ihya al-Sunnah near Yogyakarta, the leaders of this Salafi movement such as Ja'far Umar Thalib also established campus outreach and a paramilitary force, the Laskar Jihad that called for armed jihad and opposed then President Abdurrahman Wahid. ${ }^{57}$ Another well-known Islamic school that is anti-nationalism is pesantren Al-Mukmin in Ngruki. Although it is not part of the before-mentioned Salafi movement led by Thalib, it has adopted many elements of Salafism in its teachings such as militant ideologies and animosity towards the government as well as the United States and its allies. ${ }^{58}$ Al-Mukmin's curriculum teaches its students to reject the secular state in favour of an Islamic state, carry out armed jihad, and be antagonistic towards non-Muslims. According to Robert W. Hefner, a textbook outlines three stages for Muslims to implement Islamic law: establish a community of believers that opposes the unbelievers; form a well-organised army; and learn how to use firearms. ${ }^{59}$ The justification, as propagated by the leaders of Al-Mukmin, is that Islam teaches that whoever does not follow Allah's law is an infidel. The spiritual leader of the pesantren, $\mathrm{Abu}$ Bakar $\mathrm{Ba}^{\prime}$ asyir who preaches regularly at the school also reiterated the message that nationalism and democracy are violations of God's law. A common characteristic of these Islamic schools as well as their affiliated militant organisations is a tendency to indoctrinate its students and members into a totalistic worldview that is antinationalism and anti-non-Muslism.

However, it is important to point out that Islamic schools such as Ihya al-Sunnah and Al-Mukmin that champion anti-government ideology and armed jihad comprise a "miniscule proportion of the whole" ${ }^{60}$ Researchers put the figure of such schools at fewer than 20 out of a total of 50,000 Islamic schools. ${ }^{61}$ The majority of Islamic schools in Indonesia, as this article has argued, are not indoctrinatory but educative in nature. The educative tradition in these schools is evident in three main ways. First, most Islamic schools in Indonesia are keen to obtain knowledge from both religious subjects and modern 'secular' subjects. Secondly, while the traditional didactic teaching methods are still widely used in the Islamic schools, many have incorporated student-centred pedagogies so that their students do not simply learn by rote or memorisation. Thirdly, most Islamic schools provide a variety of student activities to develop the students' life skills and leadership abilities so as to encourage their students to internalise and put into practice the principles and values they have learnt. Notwithstanding its promotion of an educative tradition, many Islamic schools in Indonesia face a perennial challenge in infusing Islamic principles and values into the teaching of modern 'secular' subjects.

56 HASAN 2008: 249.

57 Ibid.: 255 .

58 Ibid.: 260

59 HEFNER 2007: 85-6.

60 AZRA / AFRIANTY / HEFNER 2007: 192.

61 Greg Barton claims that there are only five pesantren known to be closely linked to JI and teaching a jihadi interpretation of Islam, see BARTON 2005: 57. Zachary Abuza estimates that there are "some one dozen" Islamic schools that have clear ties to JI, see ABUZA 2007: 64. Sidney Jones avers that there are fewer than 20 Islamic schools across Indonesia in the network of JI schools, JONES 2005: 11. 


\section{References}

AbDul Rahman, Noor Aisha / LaI, Ah Eng (eds.). 2006. Secularism and Spirituality: Seeking Integrated Knowledge and Success in Madrasah Education in Singapore. Marshall Cavendish, Singapore.

ABUZA, Zachary. 2007. Political Islam and Violence in Indonesia . Routledge, London \& New York.

ALATAS, Syed Farid. 2006. "Knowledge and Education in Islam." In: ABDUL RAHMAN \& LAI (eds.) 2006: 166-179.

ARIFIN, H. Imron / Slamet, Muhammad. 2010. Kepimimpin Kyai: Dalam Perubahan Manajemen Pondok Pesantren: Kasus Ponpes Tebuireng Jombang [Kyai Leadership: Change Management in Boarding School: The Case of Tebuireng Jombang]. Aditya Media, Yogyakarta.

ASSYAUKANIE, Luthfi. 2009. Islam and the Secular State in Indonesia. Institute of Southeast Asian Studies Publications, Singapore.

AZRA, Azyumardi. 2014. "Reforms in Islamic Education: A Global Perspective Seen from the Indonesian Case." In: TAN (ed.) 2014: 59-75.

- / AFriAnTy, Dina / HeFNeR, Robert W. 2007. "Pesantren and Madrasa: Muslim Schools and National Ideals in Indonesia.” In: HEFNER \& ZAMAN (eds.) 2007: 172-198.

BARTON, Greg. 2005. Jemaah Islamiyah. Ridge Books, Singapore.

BURHANUdin, Jajat / JAMHARI. 2006. "Assessment of Social and Political Attitudes in Indonesia Islamic Education Institution.” Studia Islamika: Indonesian Journal for Islamic Studies, 13/3: 399-433.

DHOFIER, Zamakhsyari. 1999. The Pesantren Tradition: The Role of the Kyai in the Maintenance of Traditional Islam in Java. Arizona State University, Arizona.

GEERTZ, Clifford. 1968. Islam Observed: Religious Development in Morocco and Indonesia. The University of Chicago Press, Chicago.

HASAN, Noorhaidi. 2008. "The Salafi Madrasas of Indonesia." In: NOOR / SiKAND / VAN BRUINESSEN (eds.) 2008: 247-274.

HEFNER, Robert W. 2000. Civil Islam: Muslims and Democratisation in Indonesia. Princeton University Press, Princeton.

—. 2007. "Islamic Schools, Social Movements, and Democracy in Indonesia." In: HEFNER \& ZAMAN (eds.) 2007): 55-105.

- I Zaman, Muhammad Qasim (eds.). 2007. Schooling Islam: The Culture and Politics of Modern Muslim Education. Princeton University Press, Princeton.

HOOKER, Virginia / SAIKAL, Amin (eds.). 2004. Islamic Perspectives on the New Millennium. Institute of Southeast Asian Studies (ISEAS) Publishing, Singapore.

IDRIZ, Mesut / Al-ATTAS, Syed Ali Tawfik. 2007. The Ihazah of Abdullah Fahim: A Unique Document from Islamic Education. MPH Publishing, Selangor.

IQBAL, Muzaffar. 2009. The Making of Islamic Science. Islamic Book Trust, Kuala Lumpur.

JONES, Sidney. 2005. "Terrorism and 'Radical Islam' in Indonesia." In: VicZIANY \& WRIGHT-NeVILLE (eds.) 2005: 3-14.

KADI, Wadad / BILLEH, Victor (eds.). 2007. Islam and Education: Myths and Truths. University of Chicago, Chicago.

LuKENS-BULl, Ronald. 2005. A Peaceful Jihad: Negotiating Identity and Modernity in Muslim Java. Palgrave Macmillan, New York.

MARSCHALL, Wolfgang (ed.). 1994. Texts from the Islands: Oral and Written Traditions of Indonesia and the Malay World. University of Berne, Berne. [Ethnologica Bernica, 4].

Moten, Abdul Rashid. 2005. "Modernisation and the Process of Globalisation: The Muslim Experience and Responses." In: NATHAN \& KAMALI (eds.) 2005: 231-255.

MutALIB, Hussin. 2008. Islam in Southeast Asia. Institute of Southeast Asian Studies, Singapore.

NATHAN, K.S. / KAMALI, Mohammad Hashim (eds.). 2005. Islam in Southeast Asia: Political, Social and Strategic Challenges for the 21st Century. Institute of Southeast Asian Studies, Singapore.

NoOR, Farish A. / SiKAND, Yoginder / VAN BRuinessen, Martin (eds.). 2008. The Madrasa in Asia: Political Activism and Transnational Linkages. Amsterdam University Press, Amsterdam.

PlatZDASCH, Bernhard. 2009. Islamism in Indonesia: Politics in the Emerging Democracy. Institute of Southeast Asian Studies Publications, Singapore: 2009. 
POHL, Florian. 2007. "Islamic Education and Civil Society: Reflections on the Pesantren Tradition in Contemporary Indonesia.” In: KADI \& BILLEH (eds.) 2007: 83-103.

PRINGLE, Robert. 2010. Understanding Islam in Indonesia: Politics and Diversity. Editions Didier Millet, Singapore.

RAHMAN, Fazlur. 1982. Islam \& Modernity: Transformation of an Intellectual Tradition. University of Chicago Press, Chicago.

SAEED, Abdullah. 1999. "Towards Religious Tolerance through Reform in Islamic Education: The Case of the State Institute of Islamic Studies of Indonesia." Indonesia and the Malay World, 27/79: 177-191.

SHBOUL, Ahmad. 2004. "Islam and Globalisation: Arab World Perspectives." In: HOOKER \& SAIKAL (eds.) 2004: 43-73.

TAN, Charlene. 2011. Islamic Education and Indoctrination: The Case in Indonesia. New York: Routledge. - (ed.). 2014. Reforms in Islamic Education: International Perspectives. Bloomsbury, London.

— / ABBAS, D.B. 2009. "The 'Teach Less, Learn More' Initiative in Singapore: New Pedagogies for Islamic Religious Schools?” KEDI Journal of Education Policy, 6/1: 25-39.

VAN BRUINESSEN, Martin. 1994. "Pesantren and kitab kuning: Maintenance and Continuation of a Tradition of Religious Learning." In: MARSCHALL (ed.) 1994: 121-145. - Available online at: <http://www.let.uu.nl/ martin.vanbruinessen/personal/publications/pesantren_and_kitab_kuning.htm> (accessed 28 May 2010)

—. 2008. "Traditionalist and Islamist Pesantrens in Contemporary Indonesia." In: NOOR / SIKAND / VAN BRUINESSEN (eds.) 2008: 217-245.

—. [n.d.]. "Divergent Paths from Gontor: Muslim Educational Reform and the Travails of Pluralism in Indonesia.” <http://www.let.uu.nl/ martin.vanbruinessen/personal/publications/Bruinessen_Divergent _paths_from_Gontor.pdf> (accessed 28 May 2010).

ViCZIANY, Marika / WrighT-Neville, David (eds.). 2005. Islamic Terrorism in Indonesia: Myths and Realities. Victoria, London.

ZAKARIA, Rusydy. 2008. Indonesian Islamic Education: A Social, Historical and Political Perspective. VDM Verlag Dr. Müller.

ZuHDI, Muhammad. 2006. Political and Social Influences on Religious School: A Historical Perspective. Unpublished $\mathrm{PhD}$ dissertation, McGill University.

Charlene TAN, Nanyang Technological University, Singapore \ charlene.tan@nie.edu.sg 